\title{
Curcuma alismatifolia vase life ${ }^{(1)}$
}

\author{
BRUNO TREVENZOLI FAVERO(2) *, GIUSEPPINA PACE PEREIRA LIMA(3), \\ JOHN DOLE ${ }^{(4)}$
}

\begin{abstract}
Cut curcuma stem has a reported vase life of 7 to 21 days and this difference in vase life is probably due to a combination of different factors such as growing conditions and postharvest treatments. However, the cut flower industry needs key postharvest information for new species and cultivars to be able to effectively market the flowers. The objectives of this study was to evaluate the effect of commercial hydrator and holding solutions, commercial growth regulator formulation, floral foam, ethylene and silver thiosulfate (STS) on the postharvest handling of C. alismatifolia cultivars. Control treatment (deionized water) had better vase life than the combinations of the commercial hydrator for $4 \mathrm{~h}$ and commercial holding solution for $44 \mathrm{~h}$. Floral foam reduced vase life to 17 days from 23 days for the control treatment. The growth regulators gibberellin plus benzyladenine $\left(\mathrm{GA}_{4+7}+\mathrm{BA}\right)$ had a positive effect on the fresh weight keeping parameter, but further studies are necessary. STS did not improve vase life, nor did ethylene at $1 \mu \mathrm{L} \mathrm{L}^{-1}$ reduce it. The curcuma cultivars tested were not positively affected by vase solution composition and had an average vase life in deionized water of 21 days.
\end{abstract}

Keywords: 'Chiang Mai Pink', ethylene, floral foam, postharvest, siam tulip, STS.

\section{RESUMO}

\section{Vida de vaso de Curcuma alismatifolia}

Hastes de cúrcuma tem vida de vaso reportada entre 7 e 21 dias e esta variabilidade deve-se possivelmente a diferentes fatores como condições de cultivo, tratamentos pós-colheita e suas combinações. Entretanto, a indústria de flores de corte necessita de informações chave a respeito da pós-colheita destas novas espécies e cultivares lançadas no mercado, a fim de promover a comercialização efetiva satisfazendo os consumidores finais. Os objetivos deste trabalho foram avaliar os efeitos de diferentes soluções comerciais de hidratação e manutenção, de uma formulação comercial de reguladores vegetais, da espuma floral, do etileno e do tiossulfato de prata (STS) na pós-colheita de cultivares de C. alismatifolia. O tratamento controle (água deionizada) apresentou o melhor resultado de vida de vaso comparado às combinações da solução comercial de hidratação por 4h e da solução comercial de manutenção por 44h. A espuma floral reduziu a vida de vaso para 17 dias em comparação com o tratamento controle (23 dias). A formulação contendo giberelina e benziladenina $\left(\mathrm{GA}_{4+7}+\mathrm{BA}\right)$ teve um efeito positivo na manutenção do peso fresco das hastes, porém mais estudos são necessários para determinar o efeito desta formulação na espécie estudada. O STS não mostrou efeito positivo na vida de vaso das hastes de cúrcuma, e a aplicação de $1 \mu \mathrm{L} \mathrm{L}^{-1}$ de etileno não é prejudicial à espécie. Os cultivares de cúrcuma ornamental testados não foram afetados pela composição da solução de vaso e apresentaram uma longevidade média de 21 dias quando mantidos em água deionizada.

Palavras-chave: 'Chiang Mai Pink', etileno, espuma floral, pós-colheita, STS , tulipa do Siam

\section{INTRODUCTION}

The Curcuma genus is well known due to the culinary use of $C$. longa, whose rhizomes are dried and powdered to produce a condiment called turmeric, a base of curry spice. Other Curcuma species such as C. alismatifolia, $C$. zedoaria, C. amada and C. augustifolia have ornamental potential (NAIR, 2013). In particular, C. alismatifolia, also called Siam tulip, has potential to be used as a bedded plant, potted or cut flower. It has an attractive inflorescence with a cone-like appearance where the distal bracts are green and apical bracts are pink, purple or white, spirally arranged and closely overlapped, giving a tulip-like appearance (Figure 1) (BUNYA-ATICHART et al., 2004; NAIR, 2013).

\footnotetext{
DOI: http://dx.doi.org/10.14295/oh.v23i1.989

(1) Received in 21/11/2016 and accepted in 09/03/2017

(2) University of Copenhagen (UCPH), Faculty of Science, Crop Sciences, Tåstrup, Denmark. *Corresponding author: btf@plen.ku.dk

(3) Universidade Estadual Paulista (UNESP), Departamento de Química e Bioquímica, Botucatu-SP, Brazil.

(4) North Carolina State University (NCSU), Department of Horticultural Science, Raleigh-NC, USA.
} 


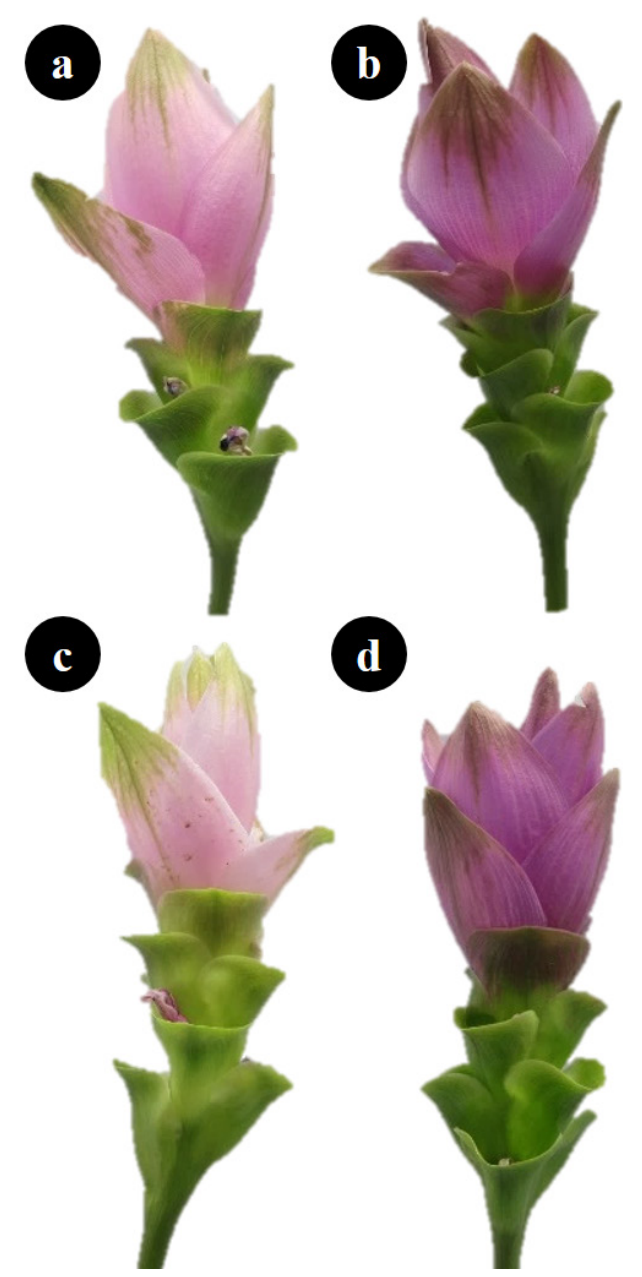

Figure 1. Inflorescences of Curcuma alismatifolia a. 'Chiang Mai Pink', b. ' 8171141 ', c. '943005' and d. '9472229'.

The vase life of this species exhibits a wide range reported, e.g. 7 to 21 days (CHUTICHUDE and CHUTICHUDE, 2012; CHUTICHUDE et al., 2011), possibly due to a number of factors such as cultivar, growing conditions and postharvest treatments. The cut flower industry needs key postharvest information for producers to effectively market new species and cultivars. Studies have shown C. alismatifolia 'Chiang Mai Pink' stems are ethylene sensitive and did not respond well to 8-HQS + sucrose, DICA + sucrose and sucrose alone in the vase solution (BUNYA-ATICHART et al., 2004). Application of 1-MCP for $8 \mathrm{~h}$ at $600 \mathrm{~nL} \mathrm{~L}^{-1}$ controlled anthocyanin degradation, but did not extend vase life of 'Chiang Mai Pink' stems (CHUTICHUDE et al., 2011). The growth regulator gibberellic acid (GA) had a great impact on maintaining fresh weight when applied after harvest, but studies differed on its effect on vase life, either positive (KJONBOON and KANLAYANARAT, 2005) or neutral (BUNYA-ATICHART et al., 2004).

Additional information is needed, including the efficacy of commercially available hydrator and/or holding solutions treatments that can be done at wholesaler level and the effect of floral foam, which is used at the retailer level (CLARK et al., 2010; DOLE et al., 2009).

The objectives of this study were to evaluate the effect of commercial hydrator and holding solutions, floral foam, silver thiosulfate and growth regulators on the postharvest performance of cut $C$. alismatifolia flowers from one cultivar and three new cultivars under development.

\section{MATERIALS AND METHODS}

Curcuma alismatifolia plants were grown in Raleigh, NC: cultivar 'Chiang Mai Pink' and lines: '943005', '9472229' and '8171141'. Rhizomes (Hawaii Clean Seed, Pahoa, HI) were planted in lily crates $(55.5 \times 36.5 \times 22.5$ $\mathrm{cm}$ ) filled with a commercial peat-based substrate (4P Fafard Conrad Fafard Inc., Agawam, MA, USA) on June 2013 and kept in a glasshouse with maximum temperature control set to $25^{\circ} \mathrm{C}$. The substrate was irrigated as need in the first two weeks with tap water and after the rhizomes started to sprout with $175 \mathrm{mg} \mathrm{L}^{-1}$ N-P-K (20-10-20), approximately twice a week. Two months after planting, enough flowers were produced to start experiments. 
The flowering stem was considered ready to harvest when the colored bracts exhibited the line-characteristic pink shade and one or two green bracts on the inflorescence basal region were opened. The same harvesting point was considered for all tested cultivars.

\section{Hydrating and holding solutions}

After harvest stems were recut to $50 \mathrm{~cm}$, divided into two groups, and treated with either deionized water (DI) or $8 \mathrm{~mL} \mathrm{~L}^{-1}$ Chrysal Professional RVB Hydrating Solution (Chrysal Americas, Miami, FL, USA) (hydrator) for $4 \mathrm{~h}$. Subsequently, one group of flowers from each solution was placed in either deionized water (DI) or $10 \mathrm{~mL} \mathrm{~L}^{-1}$ Chrysal Professional no. 2 Processing Solution (Chrysal Americas, Miami, FL, USA) (holding) for $44 \mathrm{~h}$. The chosen periods reflect an average of two days processing time between harvest and delivery of the product to retail. Afterwards, stems were placed in jars containing $500 \mathrm{~mL}$ of deionized water until stems were terminated.

\section{Gibberellin plus benzyladenine}

After harvest stems were recut to $50 \mathrm{~cm}$, treated with gibberellin + benzyladenine $\left(1.8 \% \mathrm{GA}_{4+7}+1.8 \% \mathrm{BA}\right.$, Fresco, Fine Agrochemicals, Worcester, UK) solutions at $0,0.5,1$ and $2 \mathrm{mg} \mathrm{L}^{-1}$ for $15 \mathrm{~h}$, and then placed in jars containing $500 \mathrm{~mL}$ deionized water until stems were terminated.

\section{Retailer treatments}

After harvest stems were recut to $50 \mathrm{~cm}$, placed in vases with or without floral foam and either deionized water or $10 \mathrm{~mL} \mathrm{~L}^{-1}$ Chrysal Professional no. 2 Processing Solution (Chrysal Americas, Miami, FL, USA) (holding) until stems were terminated.

\section{Ethylene sensitivity}

After harvest stems were recut to $50 \mathrm{~cm}$, treated either with deionized water or $2 \mathrm{~mL} \mathrm{~L}^{-1}$ Chrysal AVB (Chrysal Americas, Miami, FL, USA) for $4 \mathrm{~h}$ prior to $15 \mathrm{~h}$ ethylene treatment in DI water at 0 or $1 \mu \mathrm{L} \mathrm{L}^{-1}$ ethylene inside sealed containers with air forced circulation at $20^{\circ} \mathrm{C}$.

Vase life was the number of days before $50 \%$ of the pink bracts darkened, browned or wilted or $50 \%$ of the green bracts turned yellow. Furthermore, not all cultivars were tested in all experiments due to insufficient flower production.

Each treatment had 10 replicates of one stem per vase and vases were organized on benches in a completely randomized design in the postharvest evaluation room, which was held at $20 \pm 2{ }^{\circ} \mathrm{C}$ with $40-60 \%$ relative humidity and a $12 \mathrm{~h}$ photoperiod provided by cool-white fluorescent lamps. The lamps provided a photosynthetic photon flux of $\sim 20 \mu \mathrm{mol} \mathrm{m} \mathrm{m}^{-2}$ $\mathrm{s}^{-1}$ as measured at bench level with a 1078 QMSW Quantum meter (Apogee Instruments Inc., Logan, UT, USA).

Data were analyzed with help of Sisvar software (FERREIRA, 2011) using one-way ANOVA to test the influence of cultivars $\mathrm{x}$ treatments, qualitative data had means compared using Tukey's test $(\mathrm{p} \leq 0.05)$ and regression analysis was used for quantitative data.

\section{RESULTS AND DISCUSSION}

The postharvest treatments were based on the logistic steps after harvest, starting with treatments that would be administered to the flowers at the production or wholesaler facilities. Hydrator and holding solutions showed a significant interaction between cultivar $\mathrm{x}$ treatment for vase life parameter (Table 1). Based on results from the control treatments there was a difference up to 5 days in vase life between cultivars 'Chiang Mai Pink' and '8171141'.

Table 1. Vase life (days), fresh weight variation (\% of initial), and water uptake ( $\mathrm{mL}$ day $\left.^{-1}\right)$ of C. alismatifolia inflorescences treated either with deionized water (DI) or Chrysal hydration solution (H) for $4 \mathrm{~h}$ then placed in deionized water (DI) or Chrysal holding solution (P) for $44 \mathrm{~h}$ and followed by transfer to jars with $500 \mathrm{~mL}$ of deionized water until termination.

\begin{tabular}{|c|c|c|c|c|}
\hline \multirow{3}{*}{ Cultivar } & \multicolumn{4}{|c|}{ Vase life (days) } \\
\hline & \multicolumn{4}{|c|}{ Treatment } \\
\hline & DI/DI & $\mathbf{D I} / \mathbf{P}$ & H/DI & $\mathbf{H} / \mathbf{P}$ \\
\hline 'Chiang Mai Pink' & $24.5 \mathrm{Aa}$ & $22.3 \mathrm{Aa}$ & $23.8 \mathrm{Aa}$ & $23.3 \mathrm{Aa}$ \\
\hline ‘943005’ & $22.2 \mathrm{Aab}$ & 19.6 Aab & $19.0 \mathrm{Ab}$ & $20.3 \mathrm{Aab}$ \\
\hline ‘9472229’ & $22.3 \mathrm{Aab}$ & $15.3 \mathrm{ABb}$ & $18.4 \mathrm{BCb}$ & $13.5 \mathrm{Cc}$ \\
\hline \multirow[t]{2}{*}{ '8171141' } & $19.4 \mathrm{Ab}$ & $19.4 \mathrm{Aab}$ & $17.0 \mathrm{Ab}$ & $16.2 \mathrm{Abc}$ \\
\hline & \multicolumn{4}{|c|}{ Fresh weight ( $\%$ of initial) } \\
\hline \multirow{2}{*}{ Treatment } & DI/DI & $\mathbf{D I} / \mathbf{P}$ & H/DI & $\mathbf{H} / \mathbf{P}$ \\
\hline & $80.3 \mathrm{~B}$ & $82.2 \mathrm{~B}$ & $79.8 \mathrm{~B}$ & $87.2 \mathrm{~A}$ \\
\hline \multirow{3}{*}{ Cultivars } & 'Chiang Mai Pink' & ‘943005’ & '9472229' & '8171141' \\
\hline & $88.7 \mathrm{~A}$ & $78.5 \mathrm{C}$ & $78.6 \mathrm{C}$ & $83.7 \mathrm{~B}$ \\
\hline & \multicolumn{4}{|c|}{ Water uptake (mL day $\left.{ }^{-1}\right)$} \\
\hline \multirow{2}{*}{ Cultivars } & 'Chiang Mai Pink' & ‘943005' & '9472229' & '8171141' \\
\hline & $8.0 \mathrm{~A}$ & $7.8 \mathrm{~B}$ & $7.2 \mathrm{~B}$ & $7.8 \mathrm{~B}$ \\
\hline
\end{tabular}

*Means followed by different capital letters were statistically different within the line and by different lower case letters within the column ( $\leq \leq 0.05$ ). 
Vase life was not affected by these treatments in all cultivars, except for '9472229', which had higher vase life on the control treatment (DI/DI) (Table 1). In a study with vase solutions containing 8-HQC and DICA associated with sucrose and sucrose alone also showed no positive effect on vase life of 'Chiang Mai Pink' (BUNYA-ATICHART et al., 2004).

There was a significant isolated effect of treatment and cultivar on the fresh weight observations. Lower fresh weight loss occurred when the commercial hydrator solution for $4 \mathrm{~h}$ was followed by the commercial holding solution for $44 \mathrm{~h}$ than the other three treatments, but this positive effect did not increase vase life (Table 1). 'Chiang Mai Pink' maintained higher fresh weight than '8171141'; '943005' and '9472229' had the highest fresh weight loss among the four cultivars. 'Chiang Mai Pink' had greater water uptake than the other three cultivars which reflected in the superior fresh weight mentioned previously (Table 1).

Treating 'Chiang Mai Pink' stems with $\mathrm{GA}_{4+7}+\mathrm{BA}$ did not influence vase life nor water uptake; however, concentrations higher than $0.5 \mathrm{mg} \mathrm{L}^{-1}$ increased fresh weight by approximately $10 \%$ compared to control treatment (Figure 2). Similar results were obtained by Bunya-atichart et al. (2004) with application of 50 and $100 \mathrm{mg} \mathrm{L}^{-1} \mathrm{GA}_{3}$. Gibberellic acid induces the water status improvement by increasing water absorption or reducing water loss through lowering the transpiration rate (GOSZCZYNSKA et al., 1990). There is also indication of $\mathrm{GA}_{3}$ involvement in enhancing the hydrolysis of starches into sugars which contributes to improve the water balance status (EASON, 2002).

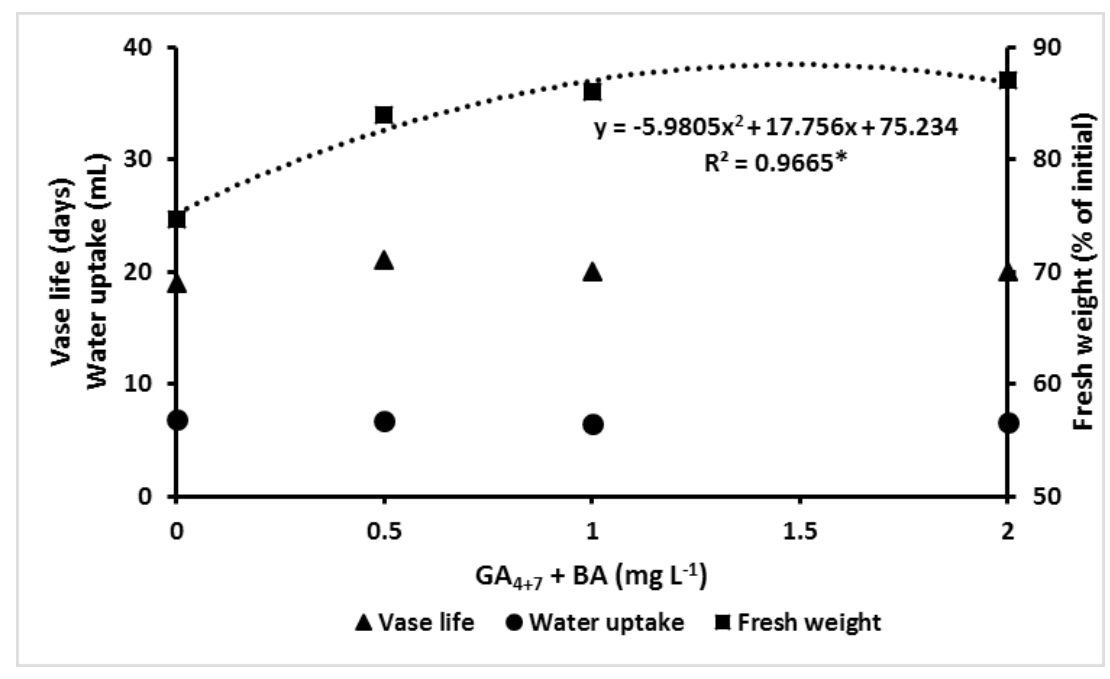

Figure 2. Vase life (days), fresh weigh variation (\%), and water uptake (mL day $\left.{ }^{-1}\right)$ of C. alismatifolia 'Chiang Mai Pink' inflorescences treated with $\mathrm{GA}_{4+7}+\mathrm{BA}$. * represents fitted model with $\mathrm{p} \leq 0.05$

Placing curcuma flowers in floral foam or keeping them continuously in commercial holding solution reduced vase life 5.6 days in average compared to stems kept in DI water only (Table 2). 'Chiang Mai Pink' had a greater vase life than the other two tested cultivars for retailer treatment. Floral foam was also not recommended for postharvest handling of cut rose stems (AHMAD et al., 2014) as it can prejudice either the solution $\mathrm{pH}$, from the foam composition, or cause vascular occlusion by foam particles covering the cut stem surface, in both situations hampering water uptake (NEUMAIER et al., 1999).
Retailer treatment showed a significant interaction between cultivar $\mathrm{x}$ treatment for the fresh weight parameter and stems placed in floral foam with holding solution treatment showed lower fresh weight loss for 'Chiang Mai Pink' and '943005' and did not differ among treatments for line ' 8171141 '. The line ' 943005 ' exhibited the lowest fresh weight when kept in deionized water without floral foam compared to the other two tested lines while no statistical difference was observed within treatments between the tested lines (Table 2). 
Table 2. Vase life (days) and fresh weight variation (\% of initial) of Curcuma alismatifolia inflorescences kept in deionized water (DI) or holding solution (H) and in jars with (F) or without (NF) floral foam until visual senescence symptoms appeared.

\begin{tabular}{|c|c|c|c|c|}
\hline \multirow{3}{*}{ Treatment } & \multicolumn{4}{|c|}{ Vase life (days) } \\
\hline & DI/NF & $\mathbf{D I} / \mathrm{F}$ & $\mathbf{H} / \mathbf{N F}$ & $\mathbf{H} / \mathbf{F}$ \\
\hline & $23.0 \mathrm{~A}$ & $17.8 \mathrm{~B}$ & $18.1 \mathrm{~B}$ & $16.1 \mathrm{~B}$ \\
\hline \multirow{3}{*}{ Cultivars } & 'Chiang Mai Pink' & ‘943005' & '8171141' & \\
\hline & $21.3 \mathrm{~A}$ & $16.9 \mathrm{~B}$ & $18.0 \mathrm{~B}$ & \\
\hline & \multicolumn{4}{|c|}{ Fresh weight variation (\%) } \\
\hline \multirow{2}{*}{ Cultivar } & \multicolumn{4}{|c|}{ Treatment } \\
\hline & DI/NF & $\mathbf{D I} / \mathbf{F}$ & $\mathrm{H} / \mathrm{NF}$ & $\mathbf{H} / \mathbf{F}$ \\
\hline 'Chiang Mai Pink' & $84.2 \mathrm{Ba}$ & $81.1 \mathrm{BCa}$ & $73.9 \mathrm{Ca}$ & $94.1 \mathrm{Aa}$ \\
\hline ‘943005’ & $76.2 \mathrm{Bb}$ & $78.7 \mathrm{Ba}$ & $78.6 \mathrm{Ba}$ & 87.2 Aab \\
\hline '8171141' & $82.3 \mathrm{Aab}$ & $78.8 \mathrm{Aa}$ & $75.2 \mathrm{Aa}$ & $83.0 \mathrm{Aa}$ \\
\hline
\end{tabular}

*Means followed by different capital letters were statistically different $(\mathrm{p} \leq 0.05)$ within the line and by different lower case letters within the column.

Chiang Mai Pink' and '8171141'stems were not affected by the ethylene treatments and did not benefit from antiethylene treatment (STS); the vase life was 17.3 or 25.5 days, respectively. Similarly, AOA did not reduce bract browning (BUNYA-ATICHART et al., 2004) and 1-MCP was not effective in extending vase life (CHUTICHUDET et al., 2010) of C. alismatifolia 'Chiang Mai Pink'. Ethylene sensitivity varies among tropical species, e.g. Anthurium sp. exhibits low sensitivity while bird of paradise is insensitive (FINGER et al., 2016).

In this study neither ethylene sensitivity nor postharvest improvement from anti-ethylene treatments were observed, where control, control + ethylene $\left(1 \mu \mathrm{L} \mathrm{L}^{-1}\right)$, STS and STS + ethylene treatments were statistically similar, in contrast with results obtained Bunya-atichart et al. (2004), where ethylene sensitivity was reported for 'Chiang Mai Pink' from concentration as low as $0.5 \mu \mathrm{L} \mathrm{L}^{-1}$. Mahadtanapuk et al. (2010) found high ACC oxidase gene expression right after harvesting in petals and bracts of 'Chiang Mai Pink', suggesting the ethylene metabolic pathway to be somehow impacting vase life.

\section{CONCLUSIONS}

In summary, the overall vase life of curcuma stems averaged at least 13 days for the shortest lived treatment and up to 24.5 days for the long lasting treatment. Thus, curcuma appears to be a durable flower and most of the standard floral treatments had little effect on vase life and flowers were not affected by ethylene. The exception is that curcuma vase life was reduced with the use of floral foam. The readily available cultivar Chiang Mai Pink had a longer vase life than the new cultivars (numbered) being developed.

\section{AUTHORS' CONTRIBUTION}

B.T.F: Creation of the idea, obtaining of funds, literature review, laboratory analysis and data collection, statistical analysis of data, manuscript preparation. G.P.P.L: Creation of the idea, obtaining of funds, orientation of the work, important suggestions incorporated to the work. J.D.: Creation of the idea, work supervision, important suggestions incorporated to the work.

\section{ACKNOWLEDGEMENTS}

To Coordenação de Aperfeiçoamento de Pessoal de Nível Superior - Capes for granting salary stipend to B.T. Favero (Process n. 0353/13-2).

\section{REFERENCES}

AHMAD, I.; DOLE, J.M.; CLARK, E.M.R.; BLAZICH, F.A. Floral foam and/or conventional or organic preservatives affect the vase-life and quality of cut rose (Rosa $\times$ hybrida L.) stems. Journal of Horticultural Science and Biotechnology, v.89, p.41-46, 2014. DOI: $<$ http://dx.doi.org/10.1080/14620316.2014.11513046>

BUNYA-ATICHART, K.; KETSA, S.; VAN DOORN, W.G. Postharvest physiology of Curcuma alismatifolia flowers. Postharvest Biology and Technology, v.34, p.219-226, 2004. DOI: <http://dx.doi.org/10.1016/j. postharvbio.2004.05.009> 
CHUTICHUDE, B.; CHUTICHUDE, P. Influence of True Flower Thinning and 1-MCP on Postharvest Changes of "Chiang Mai Pink" Patumma Cut Flower. International Journal of Agricultural Research, v.7, p.470-481, 2012. DOI: $<10.3923 /$ ijar.2012.470.481>

CHUTICHUDE, P.; CHUTICHUDE, B.; BOONTIANG, K. Effect of 1-MCP on Vase Life and Other Postharvest Qualities of Patumma (Curcuma alismatifolia) cv. Chiang Mai Pink. Trends in Horticultural Research, v.1, p.1-11, 2011. DOI: <10.3923/thr.2011.1.11>

CLARK, E.M.R.; DOLE, J.M.; CARLSON, A.S.; MOODY, E.P.; MCCALL, I.F.; FANELLI, F.L.; FONTENO, W.C. Vase life of new cut flower cultivars. HortTechnology, v.20, p.1016-1025, 2010.

DOLE, J.M.; VILORIA, Z.; FANELLI, F.L.; FONTENO, W. Postharvest evaluation of cut dahlia, linaria, lupine, poppy, rudbeckia, trachelium, and zinnia. HortTechnology, v.19, p.593-600, 2009.

EASON, J.R. Sandersonia aurantiaca: An evaluation of postharvest pulsing solutions to maximise cut flower quality. New Zealand Journal of Crop and Horticultural Science, v. 30, p. 273-279, 2002. DOI: <http://dx.doi.org/1 0.1080/01140671.2002.9514224>

FERREIRA, D.F. Sisvar: a computer statistical analysis system. Ciência e Agrotecnologia, v. 35, p. 1039-1042, 2011. DOI: $<$ http://dx.doi.org/10.1590/S1413-70542011000600001>
FINGER, F.; SILVA, T.; ARAUJO, F.; BARBOSA, J. Postharvest Quality of Ornamental Plants. In: PAREEK, S. Postharvest Ripening Physiology of Crops, Innovations in Postharvest Technology Series. Boca Raton: CRC Press, 2016. p.81-108. DOI: <10.1201/b19043-4>

GOSZCZYNSKA, D.M.; ZIESLIN, N.; MOR, Y.; HALEVY, A.H. Improvement of postharvest keeping quality of 'Mercedes' roses by gibberellin. Plant Growth Regulators, v.9, p.293-303, 1990. DOI: <10.1007/ BF00024915>

KJONBOON, T.; KANLAYANARAT, S. Effects of Gibberellic Acid on the Vase Life of Cut Patumma (Curcuma alismatifolia Gagnep.) 'Chaing Mai' Flowers Acta Horticulturae, v.673, p.525-529, 2005. DOI: $<$ https://doi.org/10.17660/ActaHortic.2005.673.70>

NAIR, K.P.P. The Ornamental Curcuma. In: The agronomy and economy of turmeric and ginger the invaluable medicinal spice crops. Oxford: Elsevier, 2013. p. 205-215. DOI: <http://dx.doi.org/10.1016/B978-0-12394801-4.00013-2>

NEUMAIER, D.; HAAS, H.P.; ROEBER, R. Longevity of cut flowers as influenced by water quality and floral foam. Acta Horticulture, v. 482. DOI: <10.17660/ActaHortic. 1999.482.10> 